\title{
PREDIKSI KURS RUPIAH TERHADAP DOLAR AMERIKA MENGGUNAKAN METODE FUZZY TIME SERIES CHEN dan HSU
}

\author{
Wulan Anggraeni ${ }^{1}$, Indra Suyahya ${ }^{2}$ \\ ${ }^{1}$ Program Studi Pendidikan Matematika, Universitas Indraprasta PGRI \\ E-mail: Wulangussetiyo@gmail.com \\ ${ }^{2}$ Program Studi Pendidikan Ekonomi, Universitas Indraprasta PGRI \\ E-mail: Indrasuyahya@gmail.com
}

\begin{abstract}
Abstrak
Tujuan dari penelitian ini adalah untuk mengetahui apakah metode fuzzy time series Chen dan Hsu dapat dipergunakan dalam memprediksi Kurs rupiah terhadap dolar Amerika. Proses peramalan menggunakan metode fuzzy time series Chen dan Hsu (2014) menggunakan data pada periode 1 April 2016 sampai dengan 18 Juni 2016. Berdasarkan hasil peramalan menggunakan metode fuzzy time series Chen dan Hsu untuk tanggal 21, 22, 23, 24, dan 25 pada bulan juni secara berturut-turut adalah Rp. 13355, Rp. 13375, Rp. 13395, Rp. 13465, Rp 13.475 dengan tingkat kesalahan peramalan sebesar $0,6 \%$. Dikarenakan tingkat kesalahan sebesaer 0,6\% maka metode fuzzy time series Chen dan Hsu dapat dipergunakan untuk memprediksi nilai tukar rupiah terhadap dolar Amerika.
\end{abstract}

Kata Kunci: fuzzy, time series, metode fuzzy, time series Hsu

\section{Pendahuluan}

Nilai tukar atau dikenal dengan kurs adalah sebuah perjanjian yang dikenal sebagai nilai tukar mata uang terhadap pembayaran saat kini atau dikemudian hari, antara dua mata uang masing-masing negara atau wilayah. Nilai tukar ditentukan berdasarkan kekuatan-kekuatan pasar dari penawaran dan permintaan sesuai dengan hukum permintaan, yaitu harga akan meningkat jika permintaan meningkat. Nilai tukar mata uang cenderung selalu berubah. Ada beberapa faktor yang menyebabkan perubahan nilai tukar, yaitu: perbedaan tingkat inflasi antara 2 negara, perbedaan tingkat suku bunga antara 2 negara, neraca perdagangan, hutang publik, rasio harga ekspor dan harga impor, kestabilan politik dan ekonomi.

Negara yang memiliki laju inflasi rendah akan lebih kuat nilai tukar mata uangnya dibandingkan dengan negara yang memiliki laju inflasi tinggi. Semakin tinggi laju inflasi suatu negara maka nilai tukar mata uang terhadap mata uang negara lain semakin melemah. Suku bunga, inflasi dan nilai tukar memiliki hubungan erat. Jika bank sentral suatu negara menaikan suku bunga, permintaan mata uang akan meningkat. Investor domestik dan luar negeri tertarik akanreturn yang lebih tinggi sehingga menginvestasikan uangnya di negara tersebut. Namun jika inflasi tinggi, maka investor akan menarik investasinya agar tidak merugi, hal ini yang membuat pihak bank sentral akan menaikan suku bunga lagi agar para investor menaruh investasi di negara tersebut, yang pada akhirnya akan menaikan nilai tukar mata uang. Sebaliknya jika bank sentral menurunkan suku bunga maka akan cenderung menurunkan nilai tukar mata uang.

Neraca perdagangan antara 2 negara berisi semua pembayaran dari hasil jual beli barang dan jasa. Neraca perdagangan suatu negara disebut defisit bila negara tersebut membayar lebih banyak ke negara rekan dagangnya dibandingkan dengan pembayaran yang diperoleh dari rekan dagangnya. Dalam hal ini negara tersebut membutuhkan lebih banyak mata uang negara partner dagang, yang menyebabkan nilai tukar mata uang negara tersebut melemah. Keadaan sebaliknya disebut surplus. Sedangkan, neraca anggaran domestik suatu negara digunakan juga untuk membiayai proyek-proyek untuk kepentingan publik dan pemerintah. Jika anggaran defisit maka hutang publik membengkak. Hutang publik akan menyebabkan naiknya inflasi. Defisit anggaran bisa ditutup dengan menjual bond pemerintah atau 
mencetak uang. Keadaan bisa memburuk bila hutang besar menyebabkan negara gagal membayar sehingga peringkat hutangnya turun. Hutang negara yang tinggi jelas akan memperlemah nilai tukar mata uang negara. Faktor lainnya adalah ratio harga ekspor. Jika ratio harga ekspor meningkat lebih cepat dari harga impor maka nilai tukar uang negara tersebut cenderung menguat. Permintaan akan barang dan jasa dari negara tersebut naik yang berarti permintaan mata uangnya juga meningkat. Keadaan sebaliknya untuk harga impor yang naik lebih cepat dari harga ekspor.

Jika ditinjau dari 6 faktor yang diuraikan di atas maka jelaslah mengapa nilai tukar mata uang Indonesia terhadap dolar Amerika selalui fluktuatif, dan akhir-akhir ini melemah. Melemahnya nilai tukar mata uang rupiah menyebabkan membengkaknya hutang publik kepada negara rekanan yang jatuh tempo. Hal ini menyebabkan krisis ekonomi di Indonesia.

Dengan demikian, meramal kurs rupiah merupakan kunci bagi pengambilan keputusan yang melibatkan transfer dana dari satu mata uang ke mata uang lain dalam suatu periode tertentu. Kesalahan pengambilan keputusan dapat menyebabkan kerugian yang fatal, bagi perusahaan multinasional, perusahaan nasional ekspor impor maupun investor pelaku spekulasi. Oleh karena itu akan dilakukan penelitian dengan judul "prediksi kurs rupiah terhadap dolar amerika menggunakan fuzzy time series model chen (studi empiris kurs harian periode 1 April 2016 sampai dengan 18 Juni 2016).

\section{Tinjauan Pustaka}

\section{A. Uang}

Uang adalah persedian aset yang bisa dengan segera digunakan untuk melakukan transaksi.Jadi rupiah ditangan masyarakat membentuk persedian aset yang bisa dengan segera digunakan untuk melakukan transaksi. Jadi rupiah yang berada di tangan masyarakat membentuk persedian uang nasional (Mankiw, 2000).

\section{B. Nilai Tukar Mata Uang (Kurs)}

Nilai tukar mata uang (kurs) adalah harga relatif dari mata uang dua negara (Mankiw, 2000).

\section{Penentuan kurs}

Berikut ini adalah uraian penentuan kurs suatu mata uang.

a. Teori Paritas International

Salah satu teori yang digunakan untuk menjelaskan kurs mata uang adalah teori paritas daya beli yang diperkenalkan oleh Gustav cassel tahun 1918. Teori paritas daya beli ini menghubungkan kurs valas dengan harga-harga komoditi yang dinyatakan dalam uang lokal di pasar international (Kuncoro, 2002). Hubungan antara kurs valas dan harga komoditi dalam doktrin paritas daya beli yaitu kurs valas akan cenderung menurun dengan proporsi yang sama dengan kenaikan harga. Paritas daya beli absolut menyatakan bahwa keseimbangan nilai mata uang dalam negeri terhadap nilai mata uang luar negeri merupakan perbandingan harga absolut dalam dan luar negeri.Paritas daya beli relatif menyatakan bahwa kurs valas merupakan suatu prosentase perbandingan perubahan harga absolut dalam negeri terhadap luar negeri.

Paritas suku bunga merupakan teori yang paling dikenal dalam keuangan internasional.Doktrin paritas suku bunga ini mendasarkan nilai kurs berdasarkan tingkat suku bunga antar negara yang bersangkutan. Dalam negara dengan sistem kurs valas bebas, tingkat bunga domestik cenderung disamakan dengan tingkat bunga luar negeri dengan memperhitungkan perkiraan laju depresiasi mata uang negara yang bersangkutan terhadap negara lain. 


\section{b. Pendekatan Perdagangan terhadap Pembentukan Kurs}

Salah satu model kurs tradisional yang sangat pentung didasarkan pada kajian terhadap arus pertukaran barang dan jasa antar negara.Artinya model ini melihat bahwa nilai tukar atau kurs antara dua mata uang dari dua negara ditentukan oleh besar kecilnya perdagangan barang dan jasa yang berlangsung di antara kedua negara tersebut.itulah sebabnya model ini lazim disebut dengan pendekatan perdagangan atau pendekatan elastisitas terhadap pembentukan kurs.

\section{Sistem Kurs Mata Uang}

Ada beberapa macam sistem kurs mata uang dalam sistem moneter internasional.Yaitu sistem kurs tetap, sistem kurs mata uang mengambang dan sistem kurs campuran (Sugiyanto, 2004).

\section{a. Sistem Kurs Tetap}

Dalam sistem kurs tetap, kurs mata uang suatu negara dinyatakan sebesar nilai tertentu terhadap mata uang negara lain. Misalnya ketika otoritas moneter Indonesia menyatakan bahwa Rp. 1640 ekuivalen dengan 1 \$ Amerika pada 12 September 1986. Dalam suatu sistem kurs tetap, kurs rupiah tersebut akan tetap dipertahankan pada tingkat tertentu. Atau setidaknya meskipun terjadi penyimpangan dari nilai yang sudah ditetapkan tadi, maka penyimpangan tersebut relatif kecil (Sugiyanto, 2004).

b. Sistem Kurs Mengambang

Sistem kurs mengambang disebut juga sebagai sistem kurs fleksibel. Dalam sistem ini, otoritas moneter sama sekali tidak melakukan campur tangan terhadap penentuan kurs mata uang. Jadi kurs selalu berfungsi untuk market clear up.

c. Sistem Kurs Campuran

Sistem kurs campuran dapat dipandang sebagai bentuk kompromi dari perdebatan atas sistem mana yang dipakai, apakah sistem kurs tetap ataukah sistem kurs mengambang. Ada beberapa bentuk sistem kurs campuran, yaitu:

1) Sistem kurs batas

Dalam sistem kurs batas ini, kurs diperbolehkan bervariasi di sekitar batas paritasnya. Gagasan dasar sistm ini sebenarnya sama dengan sistem bretton woods. Dimungkinkannya kurs bervariasi di sekitar kurs paritasnya adalah dimaksudkan untuk memberi kesempatan neraca pembayaran melakukan penyesuaian apabila posisi neraca pembayaran tersebut dalam keadaan tidak seimbang. Kelemahan sistem ini akan tidak efektif. Karena itu perlu dilakukan penyesuaian kembali atas batas-batas kurs tersebut.

2) Sistem kurs "crawling pegg"

Dalam sistem "crawling peg" kurs mata uang suatu negara diperbolehkan bervariasi di sekitar kurs paritasbta. Tetapi, nilai paritas tersebut secara teratur dilakukan penyesuaian berdasaekan posisi cadangan devisa. Dalam sistem ini, diterapkan kurs batas atas dan batasbawah. Kurs batas ini hanya dapat dipertahankan apabila tersedia cadangan devisa yang cukup.karena itu, perubahan kurs pada tingkat yang relatif kecil,dan berada pada interval kurs batas tidak akan menciptakan bahaya spekulasi (Sugiyanto, 2004)

3) Sistem kurs mengambang terkendali

Rezim kurs mengambang terkendali ditandai dengan campur tangannya otoritas moneter terhadap pergerakan kurs.Campur tangan ini bersifat bebas.Artinya, campur tangan tersebut tidak mendasarkan pada nilai 
kurs paritas.Karena itu campur tangan ini disebut sebagai "menunggu arah angin".

\section{Metodologi Penelitian}

\section{A. Pendekatan Penelitian}

Pendekatan penelitian yang digunakan dalam penelitian ini adalah penelitian kualitatif. Adapun jenis dan sumber data, populasi dan sampling beserta metode pengumpulan data akan diuraikan sebagai berikut:

\section{Jenis Sumber Data}

Data yang digunakan dalam penelitian ini adalah data tingkat suku bunga Bank Indonesia yang diterbitkan oleh Bank Indonesia setiap bulannya.Periode yang digunakan dimulai dari 1 April 2016 sampai dengan 18 Juni 2016.

\section{Populasi dan Sampling}

Populasi yang digunakan data tingkat suku bunga di Bank Indonesia. Sampel yang digunakan data tingkat suku bunga Bank Indonesia periode1 April 2016 sampai dengan 18 Juni 2016.

\section{Metode Pengumpulan data}

Metode pengumpulan data dalam penelitian ini adalah dokumentasi yang dilakukan untuk memperoleh data tingkat suku bunga bank Indonesia dalam hal ini data yang sudah diolah dan dipublikasikan secara umum oleh Bank Indonesia. Berikut ini adalah data nilai kurs rupiah pada periode 1 April 2016 sampai dengan 18 Juni 2016.

\section{B. Teknik Analisis}

Teknik analisis yang dilakukan dalam penelitian ini menggunakan data fuzzy time series Berikut ini adalah uraian dari kedua langkah metode tersebut.

\section{Metode fuzzy time series}

Metode fuzzy time series yang dipergunakan dalam penelitian ini adalah metode fuzzy time series yang dikembangkan oleh Chen dan Hsu.Berikut ini adalah langkah-langkah dari metode fuzzy time series.

\section{a) Mendefinisikan himpunan semesta}

Himpunan semesta $U=\left[D_{\min }, D_{\max }\right]$ ditentukan sesuai data historis yang ada membaginya menjadi sejumlah ganjil sub-interval dengan lebar interval yang sama besar.

b) Mengurutkan Selang Interval

Menghitung frekuensi kemunculan data dari setiap interval yang telah terbagi kemudian urutkan interval dari frekuensi yang tinggi ke rendah. Interval yang memiliki frekuensi kemunculan data tertinggi dibagi menjadi 4 sub interval, tertinggi kedua dibagi menjadi 3 sub interval, tertinggi ketiga dibagi menjadi 2 subinterval.

\section{c) Proses Fuzzifikasi}

Jika $A$ adalah himpunan fuzzy, maka $A_{1}, A_{2}, A_{3}, \ldots, A_{k}$ merupakan bilanganbilangan fuzzy yang variabel linguistiknya ditentukan sesuai dengan keadaan semesta, dimana $k$ adalah jumlah interval yang didapatkan dari langkah pertama kemudian bilangan-bilangan fuzzy tersebut didefinisikan menurut model berikut ini: 


$$
A_{k}=\left\{\begin{aligned}
\frac{1}{u_{1}}+\frac{0,5}{u_{2}}, & k=1 \\
\frac{0,5}{u_{k-1}}+\frac{1}{u_{k}}+\frac{0,5}{u_{k+1}}, & 2 \leq k \leq n-1 \\
\frac{0,5}{u_{n-1}}+\frac{1}{u_{n}}, & k=n
\end{aligned}\right.
$$

Keterangan:

$\frac{x}{u_{k}} \quad: \quad x$ merupakan derajat keanggotaan interval $u_{k}$ dalam bilangan fuzzy $A_{k}$

$u_{k}$ : sub-interval $k$ yang dibentuk dari interval $U$

$u_{k, j}$ : sub_interval $j$ yang dibentuk dari sub interval $u_{k}$

d) Menentukan Fuzzy Logical Relationship

Membangun himpunan logika fuzzy berdasarkan tingkat suku bunga, yaitu:

$$
\begin{aligned}
& A_{j} \rightarrow A_{q}, \\
& A_{j} \rightarrow A_{r},
\end{aligned}
$$

Dimana relasi logika fuzzy " $A_{j} \rightarrow A_{q}$ " memiliki arti bahwa jika tingkat suku bunga pada tahun $n-1$ adalah $A_{j}$, maka tingkat suku bunga pada tahun ke $n$ adalah sebesar $A_{q}$.

\section{e) Proses Defuzifikasi}

Proses defuzifikasi memiliki beberapa aturan yaitu:

1) Untuk data pada tahun $i=1$ (tahun pertama)

Tidak mendapatkan hasil dikarenakan tidak ada tahun sebelumnya

2) Untuk data pada tahun $i=2$ (tahun kedua)

Menghitung middle value (nilai di $\frac{1}{2}$ panjang interval) dari interva pada tahun tersebut.

3) Untuk data pada tahun $i=3$

Menghitung $P: P=\frac{1}{2} \times\left|R_{i-1}-R_{i-2}\right|$, di mana $R_{i}$ menyatakan data pada tahun ke- $i$ kemudian menghitung $Q: Q=$ setengah panjang interval dari data. Jika $P>Q$ maka perhitungan prediksinya akan upward 0,75 point (nilai di $\frac{3}{4}$ panjang interval). Jika $P=$ $Q$ maka perhitungan prediksinya akanmiddle value. Jika Jika $P<Q$ maka perhitungan prediksinya akan downward 0,25 point (nilai di $\frac{1}{4}$ panjang interval).

4) Untuk data pada tahun $i=4,5, \ldots, n$
i. $\quad$ Menghitung $W: W=\left(|| R_{i-1}-R_{i-2}|-| R_{i-2}-R_{i-3}||+R_{i-1}\right) \times 2$
ii. Menghitung $X: X=R_{i-1}-\left(|| R_{i-1}-R_{i-2}|-| R_{i-2}-R_{i-3}|| \times 2\right.$
iii. Menghitung $Y: Y=\frac{\left(\left|\left(\left|R_{i-1}-R_{i-2}\right|-\left|R_{i-2}-R_{i-3}\right|\right)\right|+R_{i-1}\right)}{2}$
iv. Menghitung $Z: Z=\frac{\left(R_{i-1}-\left(\left|R_{i-1}-R_{i-2}\right|-\left|R_{i-2}-R_{i-3}\right| \mid\right)\right)}{2}$

v. Jika $W$ atau $X$ masuk ke dalam interval data maka perhitungan prediksinya akanupward 0.75 point. Jika $Y$ atau $Z$ masuk ke dalam interval data maka perhitungan prediksinya akandownward 0.25 point. Jika $W, X, Y$ dan $Z$ tidak ada yang masuk ke dalam interval data maka perhitungan prediksinya akanmiddle value.

5) Untuk data pada tahun dengan nextstate yang belum diketahui (D) menghitung middle value interval pada data nilai fuzzy dari current state. 


\section{Pengukuran Kesalahan Peramalan}

Pengukuran kesalahan peramalan menggunakan nilai MAPE (mean absolute percentage eror. Rumus yang digunakan adalah:MAPE $=\frac{\sum_{t=1}^{n} \frac{\left|Y_{t}-\widehat{Y}_{t}\right|}{Y_{t}}}{n} \times 100$

\section{Pembahasan}

Proses peramalan menggunakan metode fuzzy time series Chen dan Hsu (2014) menggunakan data pada periode 1 April 2016 sampai dengan 18 Juni 2016. Langkahlangkah metode fuzzy time series Chen dan Hsu adalah sebagai berikut:

\section{A. Himpunan Semesta}

Berdasarkan hasil pencatatan kurs rupiah pada periode 1 April 2016 sampai dengan 18 Juni 2016, maka himpunan semesta adalah $[13.090,13695]$ dan membaginya menjadi 61 Subinterval dengan panjang interval yang sama besar. Berikut ini adalah pembagian subinterval.

Tabel 1. Interval

\begin{tabular}{|c|c|c|c|c|c|c|c|c|c|c|c|}
\hline s.i & \multicolumn{3}{|c|}{ selang } & S.i & \multicolumn{3}{|c|}{ selang } & s.i & \multicolumn{3}{|c|}{ selang } \\
\hline u1 & [13090 & - & 13100) & u22 & [13300 & - & 13310) & u43 & [13510 & - & 13520) \\
\hline u2 & [13100 & - & 13110) & u23 & [13310 & - & 13320) & u44 & [13520 & - & 13530) \\
\hline u3 & [13110 & - & 13120) & u24 & {$[13320$} & - & 13330) & u45 & [13530 & - & 13540) \\
\hline $\mathrm{u} 4$ & [13120 & - & 13130) & u25 & [13330 & - & 13340) & $\mathrm{u} 46$ & [13540 & - & 13550) \\
\hline u5 & [13130 & - & 13140) & u26 & [13340 & - & 13350) & u47 & [13550 & - & 13560) \\
\hline u6 & [13140 & - & 13150) & u27 & [13350 & - & 13360) & u48 & [13560 & - & 13570) \\
\hline u7 & [13150 & - & 13160) & u28 & [13360 & - & 13370) & u49 & [13570 & - & 13580) \\
\hline u8 & [13160 & - & 13170) & u29 & [13370 & - & 13380) & u50 & [13580 & - & 13590) \\
\hline u9 & {$[13170$} & - & 13180) & u30 & [13380 & - & 13390) & u51 & [13590 & - & 13600) \\
\hline $\mathrm{u} 10$ & [13180 & - & 13190) & u31 & [13390 & - & 13400) & u52 & [13600 & - & 13610) \\
\hline u11 & [13190 & - & 13200) & u32 & {$[13400$} & - & 13410) & u53 & [13610 & - & 13620) \\
\hline u12 & [13200 & - & 13210) & u33 & [13410 & - & 13420) & u54 & [13620 & - & 13630) \\
\hline u13 & [13210 & - & 13220) & u34 & [13420 & - & 13430) & u55 & [13630 & - & 13640) \\
\hline u14 & [13220 & - & 13230) & u35 & [13430 & - & 13440) & u56 & [13640 & - & 13650) \\
\hline u15 & [13230 & - & 13240) & u36 & {$[13440$} & - & 13450) & u57 & [13650 & - & 13660) \\
\hline u16 & [13240 & - & 13250) & u37 & {$[13450$} & - & 13460) & u58 & [13660 & - & 13670) \\
\hline u17 & {$[13250$} & - & 13260) & u38 & [13460 & - & 13470) & u59 & [13670 & - & 13680) \\
\hline u18 & [13260 & - & 13270) & u39 & {$[13470$} & - & 13480) & u60 & [13680 & - & 13690) \\
\hline u19 & [13270 & - & 13280) & $\mathrm{u} 40$ & [13480 & - & 13490) & u61 & [13690 & - & 13700] \\
\hline u20 & [13280 & - & 13290) & $\mathrm{u} 41$ & [13490 & - & 13500) & & & & \\
\hline u21 & [13290 & - & 13300) & u42 & [13500 & - & 13510 & & & & \\
\hline
\end{tabular}

\section{B. Frekuensi Kemunculan Data}

Hasil frekuensi data dalam interval adalah sebagai berikut: 
Tabel 2. Frekuensi Kemunculan Data

\begin{tabular}{|c|c|c|c|c|c|c|c|c|c|c|c|c|c|c|c|c|c|}
\hline s.i & Frek & s.i & Frek & s.i & Frek & s.i & Frek & s.i & Frek & s.i & Frek & s.i & Frek & s.i & Frek & s.i & Frek \\
\hline $\mathrm{u} 1$ & 1 & $\mathrm{u} 8$ & 4 & $\mathrm{u} 15$ & 3 & $\mathrm{u} 22$ & 1 & $\mathrm{u} 29$ & 1 & $\mathrm{u} 36$ & 0 & $\mathrm{u} 43$ & 0 & $\mathrm{u} 50$ & 0 & $\mathrm{u} 57$ & 0 \\
\hline $\mathrm{u} 2$ & 0 & $\mathrm{u} 9$ & 1 & $\mathrm{u} 16$ & 2 & $\mathrm{u} 23$ & 2 & $\mathrm{u} 30$ & 0 & $\mathrm{u} 37$ & 0 & $\mathrm{u} 44$ & 0 & $\mathrm{u} 51$ & 0 & $\mathrm{u} 58$ & 0 \\
\hline $\mathrm{u} 3$ & 0 & $\mathrm{u} 10$ & 1 & $\mathrm{u} 17$ & 0 & $\mathrm{u} 24$ & 2 & $\mathrm{u} 31$ & 1 & $\mathrm{u} 38$ & 1 & $\mathrm{u} 45$ & 0 & $\mathrm{u} 52$ & 2 & $\mathrm{u} 59$ & 2 \\
\hline $\mathrm{u} 4$ & 1 & $\mathrm{u} 11$ & 2 & $\mathrm{u} 18$ & 0 & $\mathrm{u} 25$ & 1 & $\mathrm{u} 32$ & 0 & $\mathrm{u} 39$ & 1 & $\mathrm{u} 46$ & 0 & $\mathrm{u} 53$ & 3 & $\mathrm{u} 60$ & 0 \\
\hline $\mathrm{u} 5$ & 2 & $\mathrm{u} 12$ & 4 & $\mathrm{u} 19$ & 3 & $\mathrm{u} 26$ & 1 & $\mathrm{u} 33$ & 0 & $\mathrm{u} 40$ & 0 & $\mathrm{u} 47$ & 0 & $\mathrm{u} 54$ & 0 & $\mathrm{u} 61$ & 1 \\
\hline $\mathrm{u} 6$ & 1 & $\mathrm{u} 13$ & 2 & $\mathrm{u} 20$ & 1 & $\mathrm{u} 27$ & 1 & $\mathrm{u} 34$ & 0 & $\mathrm{u} 41$ & 0 & $\mathrm{u} 48$ & 0 & $\mathrm{u} 55$ & 0 & \\
\hline $\mathrm{u} 7$ & 1 & $\mathrm{u} 14$ & 1 & $\mathrm{u} 21$ & 1 & $\mathrm{u} 28$ & 0 & $\mathrm{u} 35$ & 0 & $\mathrm{u} 42$ & 0 & $\mathrm{u} 49$ & 2 & $\mathrm{u} 56$ & 1 & \\
\hline
\end{tabular}

Interval yang memiliki frekuensi tertinggi akan dibagi menjadi 4 subinterval, frekuensi ke-2 tertinggi akan dibagi menjadi 3 subinterval, frekuensi ke-3 tertinggi akan dibagi menjadi 2 subinterval, dan yang memiliki frekuensi 0 intervalnya akan dihapus. Dari hasil tersebut, maka akan diperoleh subinterval yang baru. (Chen dan Hsu 2014). Berikut adalah data subinterval baru berdasarkan frekuensi kemunculan data.

$$
\begin{aligned}
& u_{1,1}=[13090,13100) \\
& u_{4,1}=[13120,13130) \\
& u_{5,1}=[13130,13135) \\
& u_{5,2}=[13135,13140) \\
& u_{6,1}=[13140,13150) \\
& u_{7,1}=[13150,13160) \\
& u_{8,1}=[13160,13162.5) \\
& u_{8,2}=[13162.5,13165) \\
& u_{8,3}=[13165,13167.5) \\
& u_{8,4}=[13167.5,13170) \\
& u_{9,1}=[13170,13180) \\
& u_{10,1}=[13180,13190) \\
& u_{11,1}=[13190,13195) \\
& u_{11,2}=[13195,13200) \\
& u_{12,1}=[13200,13202.5) \\
& u_{12,2}=[13202.5,13205) \\
& u_{12,3}=[13205,13207.5)
\end{aligned}
$$$$
\begin{aligned}
& u_{13,1}=[13210,13215) \\
& u_{13,2}=[13215,13220) \\
& u_{14,1}=[13220,13230) \\
& u_{15,1}=[13230,13233.33) \\
& u_{15,2}=[13233.33,13236.66) \\
& u_{15,3}=[13236.66,13240) \\
& u_{16,1}=[13240,13245) \\
& u_{16,2}=[13245,13250) \\
& u_{19,1}=[13270,13273.33) \\
& u_{19,2}=[13273.33,13276.66) \\
& u_{19,3}=[13276.66,13280) \\
& u_{20,1}=[13280,13290) \\
& u_{21,1}=[13290,13300) \\
& u_{22,1}=[13300,13310) \\
& u_{23,1}=[13310,13315) \\
& u_{23,2}=[13315,13320) \\
& u_{24,1}=[13320,13325) \\
& u_{24,2}=[13325,13330)
\end{aligned}
$$$$
\begin{aligned}
& u_{25,1}=[13330,13340) \\
& u_{26,1}=[13340,13350) \\
& u_{27,1}=[13350,13360) \\
& u_{29,1}=[13370,13380) \\
& u_{31,1}=[13390,13400) \\
& u_{38,1}=[13460,13470) \\
& u_{39,1}=[13470,13480) \\
& u_{49,1}=[13570,13575) \\
& u_{49,2}=[13575,13580) \\
& u_{52,1}=[13600,13605) \\
& u_{52,2}=[13605,13610) \\
& u_{53,1}=[13610,13613.33) \\
& u_{53,2}=[13613.33,13616.66) \\
& u_{53,3}=[13616.66,13620) \\
& u_{56,1}=[13640,13650) \\
& u_{59,1}=[13670,13675) \\
& u_{59,2}=[13675,13680) \\
& u_{61,1}=[13690,13700)
\end{aligned}
$$

\section{Proses Fuzzifikasi}

Dengan menggunakan persamaan proses fuzzifikasi, maka diperolah model fuzzifikasi sebagai berikut:

$$
\begin{aligned}
& A_{1}=\frac{1}{u_{1,1}}+\frac{0.5}{u_{4,1}} \\
& A_{2}=\frac{0.5}{u_{1,1}}+\frac{1}{u_{4,1}}+\frac{0.5}{u_{5,1}} \\
& A_{3}=\frac{0.5}{u_{4,1}}+\frac{1}{u_{5,1}}+\frac{0.5}{u_{5,2}} \\
& A_{4}=\frac{0.5}{u_{5,1}}+\frac{1}{u_{5,2}}+\frac{0.5}{u_{6,1}} \\
& A_{5}=\frac{0.5}{u_{5,2}}+\frac{1}{u_{6,1}}+\frac{0.5}{u_{7,1}} \\
& A_{6}=\frac{0.5}{u_{6,1}}+\frac{1}{u_{7,1}}+\frac{0.5}{u_{8,1}}
\end{aligned}
$$

$$
\begin{aligned}
& A_{7}=\frac{0.5}{u_{7,1}}+\frac{1}{u_{8,1}}+\frac{0.5}{u_{8,2}} \\
& A_{8}=\frac{0.5}{u_{8,1}}+\frac{1}{u_{8,2}}+\frac{0.5}{u_{8,3}} \\
& A_{9}=\frac{0.5}{u_{8,2}}+\frac{1}{u_{8,3}}+\frac{0.5}{u_{8,4}} \\
& A_{10}=\frac{0.5}{u_{8,3}}+\frac{1}{u_{8,4}}+\frac{0,5}{u_{9,1}} \\
& A_{11}=\frac{0.5}{u_{8,4}}+\frac{1}{u_{9,1}}+\frac{0.5}{u_{10,1}} \\
& A_{12}=\frac{0.5}{u_{9,1}}+\frac{1}{u_{10,1}}+\frac{0.5}{u_{11,1}}
\end{aligned}
$$

$$
\begin{aligned}
& A_{13}=\frac{0.5}{u_{10,1}}+\frac{1}{u_{11,1}}+\frac{0.5}{u_{11,2}} \\
& A_{14}=\frac{0.5}{u_{11,1}}+\frac{1}{u_{11,2}}+\frac{0.5}{u_{12,1}} \\
& A_{15}=\frac{0.5}{u_{11,2}}+\frac{1}{u_{12,1}}+\frac{0.5}{u_{12,2}} \\
& A_{16}=\frac{0.5}{u_{12,1}}+\frac{1}{u_{12,2}}+\frac{0.5}{u_{12,3}} \\
& A_{17}=\frac{0.5}{u_{12,2}}+\frac{1}{u_{12,3}}+\frac{0.5}{u_{12,4}} \\
& A_{18}=\frac{0.5}{u_{12,3}}+\frac{1}{u_{12,4}}+\frac{0.5}{u_{13,1}}
\end{aligned}
$$


Jurnal String Vol. 1 No. 1 Tahun 2016

$$
\begin{aligned}
& A_{19}=\frac{0.5}{u_{12,4}}+\frac{1}{u_{13,1}}+\frac{0,5}{u_{13,2}} \\
& A_{20}=\frac{0.5}{u_{13,1}}+\frac{1}{u_{13,2}}+\frac{0.5}{u_{14,1}} \\
& A_{21}=\frac{0.5}{u_{13,2}}+\frac{1}{u_{14,1}}+\frac{0.5}{u_{15,1}} \\
& A_{22}=\frac{0.5}{u_{14,1}}+\frac{1}{u_{15,1}}+\frac{0.5}{u_{15,2}} \\
& A_{23}=\frac{0.5}{u_{15,1}}+\frac{1}{u_{15,2}}+\frac{0.5}{u_{15,3}} \\
& A_{24}=\frac{0.5}{u_{15.2}}+\frac{1}{u_{15,3}}+\frac{0,5}{u_{16,1}} \\
& A_{25}=\frac{0.5}{u_{15,3}}+\frac{1}{u_{16,1}}+\frac{0.5}{u_{16,2}} \\
& A_{26}=\frac{0.5}{u_{16,1}}+\frac{1}{u_{16,2}}+\frac{0.5}{u_{19,1}} \\
& A_{27}=\frac{0.5}{u_{16,2}}+\frac{1}{u_{19,1}}+\frac{0.5}{u_{19,2}} \\
& A_{28}=\frac{0.5}{u_{19,1}}+\frac{1}{u_{19,2}}+\frac{0.5}{u_{19,3}} \\
& A_{29}=\frac{0.5}{u_{19,2}}+\frac{1}{u_{19,3}}+\frac{0.5}{u_{20,1}}
\end{aligned}
$$

$A_{30}=\frac{0.5}{u_{19,3}}+\frac{1}{u_{20,1}}+\frac{0.5}{u_{21,1}}$

$A_{31}=\frac{0.5}{u_{20,1}}+\frac{1}{u_{21,1}}+\frac{0.5}{u_{22,1}}$

$A_{32}=\frac{0.5}{u_{21,1}}+\frac{1}{u_{22,1}}+\frac{0.5}{u_{23,1}}$

$A_{33}=\frac{0.5}{u_{22,1}}+\frac{1}{u_{23,1}}+\frac{0.5}{u_{23,2}}$

$A_{34}=\frac{0.5}{u_{23,1}}+\frac{1}{u_{23,2}}+\frac{0.5}{u_{24,1}}$

$A_{35}=\frac{0.5}{u_{23,2}}+\frac{1}{u_{24,1}}+\frac{0.5}{u_{24,2}}$

$A_{36}=\frac{0.5}{u_{24,1}}+\frac{1}{u_{24,2}}+\frac{0,5}{u_{25,1}}$

$A_{37}=\frac{0.5}{u_{24.2}}+\frac{1}{u_{25,1}}+\frac{0.5}{u_{26,1}}$

$A_{38}=\frac{0.5}{u_{25,1}}+\frac{1}{u_{26,1}}+\frac{0,5}{u_{27,1}}$

$A_{39}=\frac{0.5}{u_{26,1}}+\frac{1}{u_{27,1}}+\frac{0,5}{u_{29,1}}$

$A_{40}=\frac{0,5}{u_{27,1}}+\frac{1}{u_{29,1}}+\frac{0,5}{u_{31,1}}$
ISSN: $2527-9661$

$$
\begin{aligned}
& A_{41}=\frac{0.5}{u_{29,1}}+\frac{1}{u_{31,1}}+\frac{0.5}{u_{38,1}} \\
& A_{42}=\frac{0.5}{u_{31,1}}+\frac{1}{u_{38,1}}+\frac{0.5}{u_{39,1}} \\
& A_{43}=\frac{0.5}{u_{38,1}}+\frac{1}{u_{39,1}}+\frac{0.5}{u_{49,1}} \\
& A_{44}=\frac{0.5}{u_{39,1}}+\frac{1}{u_{49,1}}+\frac{0.5}{u_{49,2}} \\
& A_{45}=\frac{0.5}{u_{49,1}}+\frac{1}{u_{49,2}}+\frac{0.5}{u_{52,1}} \\
& A_{46}=\frac{0.5}{u_{49,2}}+\frac{1}{u_{52,1}}+\frac{0.5}{u_{52,2}} \\
& A_{47}=\frac{0.5}{u_{52,1}}+\frac{1}{u_{52,2}}+\frac{0.5}{u_{53,1}} \\
& A_{48}=\frac{0.5}{u_{52,2}}+\frac{1}{u_{53,1}}+\frac{0.5}{u_{53,2}} \\
& A_{49}=\frac{0.5}{u_{53,1}}+\frac{1}{u_{53,2}}+\frac{0.5}{u_{53,3}} \\
& A_{50}=\frac{0.5}{u_{53,2}}+\frac{1}{u_{53,3}}+\frac{0,5}{u_{56,1}} \\
& A_{51}=\frac{0.5}{u_{53,3}}+\frac{1}{u_{56,1}}
\end{aligned}
$$

\section{Proses Defuzzifikasi}

Berikut adalah fuzzy logical relationship:
1. $A_{5} \rightarrow A_{20}$
14. $A_{12} \rightarrow A_{10}$
27. $A_{31} \rightarrow A_{33}$
40. $A_{49} \rightarrow A_{54}$
2. $A_{20} \rightarrow A_{21}$
15. $A_{10} \rightarrow A_{23}$
28. $A_{33} \rightarrow A_{36}$
41. $A_{54} \rightarrow A_{48}$
3. $A_{21} \rightarrow A_{14}$
16. $A_{23} \rightarrow A_{20}$
29. $A_{36} \rightarrow A_{29}$
42. $A_{48} \rightarrow A_{43}$
4. $A_{14} \rightarrow A_{10}$
17. $A_{20} \rightarrow A_{11}$
30. $A_{29} \rightarrow A_{34}$
43. $A_{43} \rightarrow A_{52}$
5. $A_{10} \rightarrow A_{3}$
31. $A_{34} \rightarrow A_{42}$
44. $A_{52} \rightarrow A_{40}$
6. $A_{3} \rightarrow A_{2}$
18. $A_{11} \rightarrow A_{16}$
32. $A_{42} \rightarrow A_{44}$
45. $A_{40} \rightarrow A_{25}$
7. $A_{2} \rightarrow A_{1}$
20. $A_{16} \rightarrow A_{13}$
33. $A_{44} \rightarrow A_{47}$
46. $A_{25} \rightarrow A_{22}$
8. $A_{1} \rightarrow A_{24}$
21. $A_{13} \rightarrow A_{7}$
34. $A_{47} \rightarrow A_{47}$
47. $A_{22} \rightarrow A_{32}$
9. $A_{24} \rightarrow A_{9}$
22. $A_{7} \rightarrow A_{26}$
35. $A_{47} \rightarrow A_{52}$
48. $A_{32} \rightarrow A_{38}$
10. $A_{9} \rightarrow A_{16}$
23. $A_{26} \rightarrow A_{30}$
36. $A_{52} \rightarrow A_{49}$
49. $A_{38} \rightarrow A_{27}$
11. $A_{16} \rightarrow A_{6}$
24. $A_{30} \rightarrow A_{37}$
37. $A_{49} \rightarrow A_{45}$
50. $A_{27} \rightarrow A_{41}$
12. $A_{6} \rightarrow A_{3}$
25. $A_{37} \rightarrow A_{27}$
38. $A_{45} \rightarrow A_{51}$
13. $A_{3} \rightarrow A_{12}$
26. $A_{27} \rightarrow A_{31}$
39. $A_{51} \rightarrow A_{49}$
51. $A_{41} \rightarrow A_{36}$
52. $A_{36} \rightarrow A_{39}$

Setelah dilakukan proses defuzzifikasi maka akan diperoleh hasil prediksi. Hasil prediksi dapat dilihat pada tabel 3 .

Tabel 3. Hasil Prediksi (dalam Rp)

\begin{tabular}{|c|c|c|l|c|c|c|c|}
\hline Tgl & Kurs & Prediksi & Trend & Tgl & Kurs & Prediksi & Trend \\
\hline $01 / 04 / 2016$ & 13200 & - & & $12 / 05 / 2016$ & 13299 & 13295 & middle point \\
\hline $04 / 04 / 2016$ & 13145 & 13145 & middle point & $13 / 05 / 2016$ & 13311 & 13312.5 & middle point \\
\hline $05 / 04 / 2016$ & 13217 & 13218.75 & upward 0.75 & $16 / 05 / 2016$ & 13328 & 13327.5 & middle point \\
\hline $06 / 04 / 2016$ & 13223 & 13225 & middle point & $17 / 05 / 2016$ & 13278 & 13.278 .325 & middle point \\
\hline $07 / 04 / 2016$ & 13197 & 13197.5 & middle point & $18 / 05 / 2016$ & 13319 & 13317.5 & middle point \\
\hline $08 / 04 / 2016$ & 13169 & 13168.75 & middle point & $19 / 05 / 2016$ & 13467 & 13465 & middle point \\
\hline
\end{tabular}




\begin{tabular}{|c|c|c|l|l|l|c|l|}
\hline $11 / 04 / 2016$ & 13134 & 13132.5 & middle point & $20 / 05 / 2016$ & 13573 & 13572.5 & middle point \\
\hline $12 / 04 / 2016$ & 13123 & 13125 & upward 0.75 & $23 / 05 / 2016$ & 13607 & 13607.5 & middle point \\
\hline $13 / 04 / 2016$ & 13096 & 13095 & middle point & $24 / 05 / 2016$ & 13606 & 13607.5 & middle point \\
\hline $14 / 04 / 2016$ & 13238 & 13.238 .325 & middle point & $25 / 05 / 2016$ & 13671 & 13672.5 & middle point \\
\hline $15 / 04 / 2016$ & 13166 & 13166.25 & middle point & $26 / 05 / 2016$ & 13615 & 13.614 .995 & middle point \\
\hline $18 / 04 / 2016$ & 13204 & 13206.75 & middle point & $27 / 05 / 2016$ & 13575 & 13577.5 & middle point \\
\hline $19 / 04 / 2016$ & 13150 & 13155 & middle point & $30 / 05 / 2016$ & 13641 & 13645 & middle point \\
\hline $20 / 04 / 2016$ & 13133 & 13132.5 & middle point & $31 / 05 / 2016$ & 13615 & 13.614 .995 & middle point \\
\hline $21 / 04 / 2016$ & 13182 & 13185 & middle point & $02 / 06 / 2016$ & 13695 & 13695 & middle point \\
\hline $22 / 04 / 2016$ & 13169 & 13175 & middle point & $03 / 06 / 2016$ & 13612 & 13.611 .665 & middle point \\
\hline $25 / 04 / 2016$ & 13235 & 13.234 .995 & middle point & $06 / 06 / 2016$ & 13478 & 13475 & middle point \\
\hline $26 / 04 / 2016$ & 13215 & 13217.5 & middle point & $06 / 06 / 2016$ & 13671 & 13672.5 & middle point \\
\hline $27 / 04 / 2016$ & 13173 & 13175 & middle point & $07 / 06 / 2016$ & 13375 & 13375 & middle point \\
\hline $28 / 04 / 2016$ & 13204 & 13203.75 & middle point & $08 / 06 / 2016$ & 13241 & 13242.5 & middle point \\
\hline $29 / 04 / 2016$ & 13204 & 13203.75 & middle point & $09 / 06 / 2016$ & 13231 & 13.231 .665 & middle point \\
\hline $02 / 05 / 2016$ & 13192 & 13192.5 & middle point & $10 / 06 / 2016$ & 13309 & 13305 & middle point \\
\hline $03 / 05 / 2016$ & 13162 & 13161.25 & middle point & $13 / 06 / 2016$ & 13341 & 13345 & middle point \\
\hline $04 / 05 / 2016$ & 13246 & 13247.5 & middle point & $14 / 06 / 2016$ & 13273 & 13.271 .665 & middle point \\
\hline $09 / 05 / 2016$ & 13284 & 13285 & middle point & $15 / 06 / 2016$ & 13398 & 13395 & middle point \\
\hline $10 / 05 / 2016$ & 13333 & 13335 & middle point & $16 / 06 / 2016$ & 13327 & 13327.5 & middle point \\
\hline $11 / 05 / 2016$ & 13271 & 13.271 .665 & middle point & $17 / 06 / 2016$ & 13358 & 13355 & middle point \\
\hline
\end{tabular}

Setelah dilakukan perhitungan tingkat keasalahan, diperoleh bahwa tingkat kesalahan peramalan adalah sebesar $0,6 \%$, oleh karena itu, metode fuzzy time series hsu dan chen dapat dipergunakan untuk memprediksi nilai kurs rupiah terhadap dolar Amerika. Sehingga, hasil peramalan untuk tanggal 21, 22, 23, 24, dan 25 pada bulan juni secara berturut-turut adalah Rp. 13355, Rp. 13375, Rp. 13395, Rp. 13465, Rp 13.475.

\section{Simpulan dan Saran}

Berikut ini adalah simpulan dan saran dari hasil penelitian yang dilakukan:

\section{Simpulan}

Berdasarkan hasil peramalan menggunakan metode fuzzy time series Chen dan Hsu untuk tanggal 21, 22, 23, 24, dan 25 pada bulan juni secara berturut-turut adalah Rp. 13355, Rp. 13375, Rp. 13395, Rp. 13465, Rp 13.475 dengan tingkat kesalahan peramalan sebesar 0,6\%. Sehingga dapat disimpulkan bahwa metode fuzzy time series Chen dan Hsu dapat dipergunakan untuk memprediksi kurs rupiah terhadap dolar Amerika.

\section{Saran}

Masih banyak metode peramalan yang dapat digunakan dalam memprediksi nilai tukar rupiah, diantaranya adalah menggunakan metode Arima, Metode holt double exponential smoothing, dan lain-lain. Untuk itu dapat dikembangkan cara memprediksi nilai tukar rupiah terhadap dolar Amerika dan hasil yang diperoleh dapat dibandingkan dengan hasil pada penelitian ini. 


\section{Daftar Pustaka}

Atmaja, A. (2002). Analisa pergerakan nilai tukar rupiah terhadap dolar Amerika Setelah Diterapkannya kebijakan sistem nilai tukar mengambang bebas di Indonesia. Jurnal akuntansi \& keuangan Vol 4, No. 1 Mei 2002.69-78.

Chen, S.M., Hsu CC. (2004). A New Method to Forecast Enrollments Using Fuzzy Tim Series, International Journal Of Applied Science and Enginerring. 2,3: 234-244.

Sugiyanto, F.X. (2004). Faktor-Faktor yang Mempengaruhi Perilaku Kurs Rupiah Terhadap dolar Amerika Serikat Di Indonesia tahun 1986-1997: Sintesis Pendekatan Moneter Dan Pendekatan Portofolio. Disertasi Program Pascasarjana Universitas Airlangga, Surabaya. Tidak dipublikasikan.

Juanda, B., Junaidi. (2012). Ekonometrika Deret Waktu. Bogor: IPB Press.

Kuncoro, Suhardjono. (2002). Manajemem Perbankan (Teori dan Aplikasi). Edisi ke-6. Jakarta: Raja Grafindo Persada.

Mankiw, G. (2000). Teori Ekonomi Makro. Jakarta: PT Erlangga.

Mishkin. F.S (2004). The Economics Of MoneyBanking and Financial Market. New York: Pearson Addison Wesley.

Mankiw, G. (2000). Makroekonomi. Jakarta: Erlangga.

Rahardja,P. (2014). Teori Ekonomi Makro. Depok: Lembaga Penerbit Fakultas Ekonomi Universitas Indonesia.

Rinjin, K. (2000). Pengantar Perbankan dan Lembaga Keuangan Bukan Bank. Jakarta: Gramedia.

Sukirno, S. (2014). Makroekonomi Teori Pengantar. Jakarta: PT Raja Grafindo Persada.

Sugiarto dan Harijono.(2000). Peramalan Bisnis. Jakarta: Gramedia.

Suliyanto.(2011). Ekonometrika Terapan. Yogyakarta: PT Andi Yogyakarta. 